\title{
NAGY VAS-OXID-TARTALMÚ NANOKRISTÁLYOS ALUMINO-BOROSZILIKÁT ÜVEGEK
}

\section{NANO-CRYSTALLIZED ALUMINO-BOROSILICATE GLASSES WITH HIGH IRON CONTENT}

\author{
Bitay Enikő ${ }^{1}$, Kacsó Irén ${ }^{2}$, Kormos Fiammetta $^{3}$, Holczer Emil ${ }^{3}$, Veress Erzsébet ${ }^{4}$ \\ ${ }^{1}$ Sapientia Erdélyi Magyar Tudományegyetem, Marosvásárhelyi Kar, 540485 \\ Romania, Marosvásárhely/Târgu-Mureș, OP 9, CP 4, Tel.+40-751-016063, \\ ebitay@ms.sapientia.ro \\ ${ }^{2}$ National Institute for Research and Development of Isotopic and Molecular Tech- \\ nologies INCDTIM, OP 5 CP 700, 400293, Cluj, Romania, Tel. +40 745- 645670, \\ iren.kacso@gmail.com \\ ${ }^{3}$ DEKRA Certification SRL, 131 Brâncuşi, RO-400458 Cluj/Kolozsvár, Tel/Fax +40 \\ 264443598,dekra@dekracert.ro \\ ${ }^{4}$ Erdélyi Múzeum-Egyesület, 400750 Romania, Cluj/Kolozsvár, OP 1 CP 191, Tel. \\ +40-743-119275, veresserzsebet@gmail.com
}

\begin{abstract}
Compositional and structural characteristics as well as magnetic properties of high iron oxide containing borosilicate glasses prepared by the usual melt-quenching procedure were studied using FT-IR spectroscopy, XRD, optical microscopy and magnetic susceptibility determinations. The resulted glasses were all devitrified to some extent, with mainly hematite and magnetite nanocrystals separated in the glassy matrix. According to the magnetic susceptibility results, the $\mathrm{Fe}_{2} \mathrm{O}_{3} / \mathrm{FeO}$ rate in all glasses shifted towards $\mathrm{Fe}_{2} \mathrm{O}_{3}: \mathrm{FeO}=1: 1$, favorizing the magnetite formation.
\end{abstract}

Keywords: Fe-borosilicate glasses, magnetic susceptibility, FT-IR, XRD, optical microscopy

\section{Összefoglalás}

Hagyományos olvasztással-dermesztéssel előállított, nagy vas-oxid-tartalmú aluminoboroszilikát üvegek mágneses tulajdonságait, kristályosodását és szerkezeti rendezettségét vizsgáltuk mágneses szuszceptibilitás méréssel, FT-IR spektroszkópiával, röntgendiffraktometriával (XRD) és optikai mikroszkópiával $(\mathrm{OM})$ a fö rácsképző oxidok $\left(\mathrm{SiO}_{2}, \mathrm{~B}_{2} \mathrm{O}_{3}\right)$ viszonylagos kezdeti mennyiségének és a kezdeti $\mathrm{Fe}_{2} \mathrm{O}_{3} / \mathrm{FeO}$ aránynak függvényében. Az OM, FT-IR és XRD adatok alapján az üvegek kristályosodása, lokális szerkezete és szerkezeti rendezettsége megfelel a kiinduló oxidösszetétel alapján az irodalmi adatok szerint várhatónak. A mágneses szuszceptibilitás adatokból következően az üvegolvadékban beálló $\mathrm{Fe}(\mathrm{II})-\mathrm{Fe}(\mathrm{III})$ egyensúly minden esetben a magnetit keletkezésének kedvező 1:1 $\mathrm{Fe}_{2} \mathrm{O}_{3}: \mathrm{FeO}$ értékhez közelít. A következtetést az XRD- és OM-vizsgálat alátámasztja, igazolva, hogy az üveges mátrixban a hematitkrisztallitok mellett magnetit is van.

Kulcsszavak: vas-oxidos boroszilikát üvegek, mágneses szuszceptibilitás, FT-IR, XRD, OM 


\section{Mágneses oxidüvegek}

A mágneses oxidüvegek vitrokrisztallin anyagok (üvegkerámiák), amelyek a szerkezetükben homogén eloszlásban levő mikro- és/vagy nanoméretü mágneses krisztallitoknak köszönhetően mágneses tulajdonságokkal rendelkeznek. A mágneses krisztallitok anyaga átmenetifémek és ritkaföldfémek egyszerü, illetve vegyes oxidja. Az egyszerü oxid gyakran $\mathrm{Fe}_{2} \mathrm{O}_{3}$, a vegyesoxidok többnyire $\mathrm{M}^{\mathrm{II}} \mathrm{Fe}_{2} \mathrm{O}_{4}$ típusú ferritek $\left(\mathrm{M}^{\mathrm{II}}=\mathrm{Ba}, \mathrm{Sr}, \mathrm{Zn}, \mathrm{Mn}, \mathrm{Fe}, \mathrm{Ni}, \mathrm{Co}\right.$, stb., leggyakrabban $\mathrm{Fe}_{3} \mathrm{O}_{4}$ ) vagy $\mathrm{ABO}_{3}$ általános képletü perovszkitok: $\mathrm{A}=\mathrm{M}^{\mathrm{II}}(\mathrm{Ba}, \mathrm{Sr})$ és/vagy $\mathrm{M}^{\mathrm{I}}$ (Na, Li); $\mathrm{B}=\mathrm{Ti}, \mathrm{Zr}, \mathrm{Nb}, \mathrm{Ta}$, ritkábban $\mathrm{Fe}$ [1-10]. Az alapösszetétel megválasztásakor fontos szempont, hogy az üveg a felhasználási helyre jellemző körülményekből adódó környezeti hatásoknak ellenálljon. Ennek megfelelöen a rácsképző oxid $\mathrm{SiO}_{2}, \mathrm{~B}_{2} \mathrm{O}_{3}, \mathrm{Al}_{2} \mathrm{O}_{3}, \mathrm{P}_{2} \mathrm{O}_{5}, \mathrm{Bi}_{2} \mathrm{O}_{3}, \mathrm{PbO}$ vagy ezek keveréke. A rácsmódosítók alkálifém-oxidok $\left(\mathrm{Na}_{2} \mathrm{O}, \mathrm{K}_{2} \mathrm{O}, \mathrm{Li}_{2} \mathrm{O}\right)$, alkáliföldfém-oxidok ( $\mathrm{CaO}, \mathrm{BaO}, \mathrm{SrO})$, illetve az amorf üvegmátixban kiváló mágneses krisztallit-fázist képző és az elektromos, mágneses és optikai tulajdonságokat biztosító átmenetifém-oxidok $\left(\mathrm{ZnO}, \mathrm{PbO} ; \mathrm{Fe}_{2} \mathrm{O}_{3}\right.$, $\mathrm{V}_{2} \mathrm{O}_{5}, \mathrm{MnO}_{2}, \mathrm{Cu}_{2} \mathrm{O}, \mathrm{CuO}, \mathrm{CeO}_{2}, \mathrm{Cr}_{2} \mathrm{O}_{3}$, $\left.\mathrm{MoO}_{3}, \mathrm{WO}_{3}, \mathrm{CoO}, \mathrm{UO}_{3}\right)$. Az átmenetifémoxidok [11-14] szerepe kettős: a rácsmódosító funkció mellett rácsképzőként is megnyilvánul(hat)nak.

Az oxidüvegekre általánosan jellemző kémiai stabilitásukkal és viszonylag egyszerü alakíthatóságukkal társult különleges elektromos, mágneses, optikai tulajdonságaikból adódó számos alkalmazási lehetőségüknek köszönhetően a mágneses oxidüvegek elméleti és alkalmazott kutatása az utóbbi években gyors fejlődésnek indult A felhasználási lehetőségek az információtechnológiától az orvosi alkalmazásokig terjednek, de alkalmasak egyes környezetszennyező hulladékok hasznosításában is: egyes nehézfémhulladékok (hőerőmühamu, kohósalak, nukleáris hulladék, kalcinált háztartási hulladék) üvegbe olvasztásakor mágneses üveg keletkezik) [15-19].

A mágneses oxidüvegek nagyobb menynyiségben való előállítása a hagyományos üveggyártásnak megfelelően homogén olvadékuk gyors lehütésével történik. Természetesen vékonyrétegként is előállíthatók az ismert kémiai vagy fizikai leválasztási módszerekkel. Az alkalmazás által megkívánt fizikai (technikai) tulajdonságok mindkét esetben a kristályosodási folyamat gondos ellenőrzése (irányítása) révén biztosíthatók. Az irányított kristályosodás (devitrifikáció) érdekében a kiinduló oxidkeveréknek tartalmaznia kell a nanokrisztallitokat képző oxidokat (például $\mathrm{Fe}_{2} \mathrm{O}_{3}$ adalékot), az elkészült üveget pedig megfelelö hőkezelésnek vetik alá. Az irányítottan kristályosodott anyag makroszkopikusan homogén, és optimális esetben csak a kívánt krisztallittípust tartalmazza, megfelelő méreteloszlásban és koncentrációban.

A jelen dolgozat a kolozsvári Raluca Ripan Kémiai Kutatóintézetben előállított, nagy vas-oxid-tartalmú alumino-boroszilikát üvegek tulajdonságainak vizsgálata során nyert egyes eredményeket mutatja be. A hat oxidkomponenst tartalmazó üvegeket azonos körülmények között, hagyományos olvasztással-dermesztéssel állítottuk elö, utólagos hőkezelésnek nem vetettük alá. A mágneses szuszceptibilitás mérése segítségével követtük az üvegolvasztás során beálló, dermesztéssel „befagyasztott” Fe(II)$\mathrm{Fe}(\mathrm{III})$ egyensúly változását a fó rácsképző oxidok $\left(\mathrm{SiO}_{2}, \mathrm{~B}_{2} \mathrm{O}_{3}\right)$ arányának, illetve az állandó $\mathrm{SiO}_{2} / \mathrm{B}_{2} \mathrm{O}_{3}$ arány mellett adalékolt $\mathrm{Fe}_{2} \mathrm{O}_{3}$ és $\mathrm{FeO}$ arányának függvényében; optikai mikroszkópia, FT-IR spektroszkópia, XRD alkalmazásával pedig vizsgáltuk az üvegek kristályosodását és (lokális) szerkezeti rendezettségét. 


\section{Az üvegek előállítása, jellemzése}

\subsection{Az üvegek összetétele, szintézise}

A teljesen száraz, finomra porított, $1 \mathrm{mg}$ pontossággal bemért, analitikai tisztaságú kiindulóanyagokból készült (oxidok, karbonátok, bórsav), zárt rendszerben homogenizált, megfelelő összetételű kiinduló-keverékek olvasztása platinatégelyben, magas hömérsékletủ KO II típusú kemencében történt, levegö jelenlétében, A kiinduló anyagok közül az $\mathrm{Al}_{2} \mathrm{O}_{3}, \mathrm{FeO}$ és $\mathrm{Fe}_{2} \mathrm{O}_{3}$ Fluka termék, a többi „Reactivul București” termék volt.

A kiinduló összetételeket az 1. táblázat foglalja össze.

1. táblázat. A vizsgált üvegek összetétele

\begin{tabular}{|l|l|l|l|l|l|l|}
\hline \multirow{2}{*}{ Üvegtipus } & \multicolumn{6}{|c|}{ Komponensek (mol\%) } \\
\cline { 2 - 7 } & $\mathrm{SiO}_{2}$ & $\mathrm{~B}_{2} \mathrm{O}_{3}$ & $\mathrm{Na}_{2} \mathrm{O}$ & $\mathrm{Al}_{\mathbf{2}} \mathrm{O}_{3}$ & $\mathrm{Fe}_{2} \mathrm{O}_{3}$ & $\mathrm{FeO}$ \\
\hline $\mathrm{R} 20$ & 32,4 & 34,4 & 14 & 3,7 & 7,8 & 7.8 \\
\hline $\mathrm{R} 21$ & 35,0 & 30,0 & 15 & 4,0 & 8,0 & 8,0 \\
\hline $\mathrm{R} 22$ & 40,0 & 25,0 & 15 & 4,0 & 8,0 & 8,0 \\
\hline $\mathrm{R} 23$ & 40,0 & 25,0 & 15 & 4,0 & 16,0 & - \\
\hline $\mathrm{R} 24$ & 40,0 & 25,0 & 15 & 4,0 & - & 16,0 \\
\hline
\end{tabular}

A 100 g kiinduló keveréket tartalmazó tégelyt a kályhával együtt fütöttük fel. A felfütést $800^{\circ} \mathrm{C}$-ig 5 fok $/ \mathrm{min}$ sebességgel, majd a következö diagram szerint vezettük: $800{ }^{\circ} \mathrm{C}(30 \mathrm{~min}) \rightarrow 1000{ }^{\circ} \mathrm{C}(15 \mathrm{~min}) \rightarrow$ $1200{ }^{\circ} \mathrm{C}(30 \mathrm{~min}) \rightarrow 1300{ }^{\circ} \mathrm{C}(60 \mathrm{~min}) \rightarrow$ $1400{ }^{\circ} \mathrm{C}(60 \mathrm{~min}) \rightarrow 1450{ }^{\circ} \mathrm{C}$ (szintézis, 180 min) $\rightarrow 1350{ }^{\circ} \mathrm{C}$ (letisztulás, $\left.60 \mathrm{~min}\right) \rightarrow$ $1300^{\circ} \mathrm{C}$ (megnyugvás, $30 \mathrm{~min}$ ) $\rightarrow$ kiöntés. Az olvadékot a homogenizálódás érdekében $1300^{\circ} \mathrm{C}$ fölött mintegy 15 percenként platina keverővel mechanikusan kevertük.

A szintézis menetét ismételt cseppminta-vétellel ellenőriztük.

A szintézis befejeztével (a mintaként kivett csepp optikailag teljesen tiszta, homogén) az olvadékot $3 \mathrm{~mm}$ vastag rozsdamentes acéllemezre öntöttük ki, majd 10 fok/min sebességgel hagytuk a szobahömérsékletig hűlni.

\subsection{Az üvegek vizsgálata}

\subsubsection{Mágneses szuszceptibilitás mérések}

\subsubsection{A mágneses szuszceptibilitásról [20,21]}

Külső mágneses tér hatására a spontán mágneses momentummal rendelkező és a mágneses momentum nélküli atomok is mágneseződnek: a mágneses tériránnyal ellentétes irányítású járulékos mágneses momentum indukálódik bennük (diamágneses folyamat). A spontán mágneses momentummal rendelkező atomok ezenfelül rendeződni is igyekeznek, a tér irányításának megfelelően (paramágneses folyamat). Viszonylag kis térerejü külső mágneses térben a diamágneses folyamat során mágnesezett anyag $M$ mágnesezettsége (térfogategységre eső mágneses momentuma) a $H$ mágneses térerősség függvényében lineárisan változik:

$$
\mathrm{M}=\chi \mathrm{H}
$$

$\chi$ (a térfogati mágneses szuszceptibilitás) dimenzió nélküli mennyiség, az anyagok mágnesezhetőségének mértéke.

Paramágneses atomok hiányában a diamágneses anyagok eredő mágneses szuszceptibilitása az indukált mágneses momentum irányításából következően $\chi<0$. $\mathrm{Ha}$ az anyag paramágneses atomokat (is) tartalmaz, a fellépö és a diamágneses folyamat hatását rendszerint felülmúló paramágneses folyamat következtében az eredő mágneses szuszceptibilitás $\chi>0$ (az anyag paramágneses). A diamágneses szuszceptibilitás hömérséklettöl független, a paramágneses anyagok mágneses szuszceptibilitása hömérsékletfüggö. Mind a diamágneses, mind a paramágneses anyagok indukált mágnesezettsége megszünik a külső tér megszünésével.

A gyakorlatban az anyagok mágneses viselkedésének jellemzésére a $\chi_{\mathrm{M}}$ fajlagos mágneses szuszceptibilitás és a $\chi_{\mathrm{A}}$ moláris mágneses szuszceptibilitás használatos:

$$
\chi_{\mathrm{M}}=\chi / \mathrm{d} \quad d \text {-sürüség }
$$




\section{$\chi_{\mathrm{A}}=\chi \cdot \mathrm{A} / \mathrm{d} \quad A-$ móltömeg}

Az oxidok, oxidvegyületek (oxidüvegek és kerámiák is) általában diamágnesesek, $\chi_{\text {dia }}$ diamágneses szuszceptibilitásuk a kémiai összetételnek megfelelően:

$$
\chi_{\text {dia }}=\sum \chi_{\mathrm{Ai}} \cdot \mathrm{c}_{\mathrm{i}} / \mathrm{A} \text {, }
$$

ahol $c_{i}$ az $i$ típusú oxid mólszázalékos aránya; $\chi_{A i}$ az $i$ oxid moláris mágneses szuszceptibilitása; $A$ az átlagolt móltömeg.

A paramágneses ionokat kis mennyiségben tartalmazó paramágneses anyagokban a mágneses ionok egymástól elszigeteltek, külső mágneses tér hiányában az atomi mágneses momentumok irányeloszlása rendezetlen; paramágneses szuszceptibilitásának hőmérsékletfüggését a Curie-törvény írja le:

$$
\chi=\mathrm{C} / \mathrm{T} \text {. }
$$

A kifejezésben $C$ az anyagspecifikus $C$ urieállandó, $T$ az abszolút hőmérséklet.

Nagyobb mennyiségü mágneses iontartalom esetében, vagy ha az anyag alapvetően átmenetifém oxidokból áll, a mágneses ionok kölcsönhatásba lépnek, és a mágneses momentumok irányítása szerint kisebbnagyobb doménekbe rendeződnek. Ha a doménekben az atomi momentumok adott hőmérséklet alatt azonos irányúak, az anyag ferromágneses, ha azonos nagyságúak és váltakozó irányúak, az eredő mágneses momentum nulla (az anyag antiferromágneses), ha pedig váltakozó irányúak, de nagyságuk eltérő, az eredő mágneses momentum kisebb, de nullától különböző (az anyag ferrimágneses). Ezeknél az anyagoknál az $\mathrm{M}$ és $\mathrm{H}$ közötti összefüggés nem lineáris $(\mathrm{M} \neq \chi \mathrm{H})$, a mágneses szuszceptibilitás hőmérséklet-függése pedig a Curie-Weiss-törvénynek felel meg:

$$
\chi=\mathrm{C} /\left(\mathrm{T} \pm \theta_{\mathrm{p}}\right) \text {. }
$$

A $\theta_{p}$ kritikus hömérséklet a ferromágnesesparamágneses átalakulás hőmérséklete. Ha a hőmérséklet $\theta_{p}$ értékét meghaladja, az anyag másodrendü fázisátalakulással paramágnesessé válik: az atomi momentumok megmaradnak, de a domének mágnes rendeződése megszünik.
A ferro- és ferrimágneses anyagok kritikus hőmérsékletének neve Curie-hömérséklet $\left(T_{C}\right)$, az antiferromágneses anyagoké Neélhömérséklet $\left(T_{N}\right)$. Ferromágneses anyagokra nézve $\theta_{p}$ pozitív, ferri- és antiferromágneses anyagok esetében negatív. $\mathrm{Az} \quad \alpha-\mathrm{Fe}_{2} \mathrm{O}_{3}$ (hematit) antiferromágneses, $T_{N}=960 \mathrm{~K}$, a ferrimágneses $\quad \gamma-\mathrm{Fe}_{2} \mathrm{O}_{3} \quad$ (maghemit) pontosabban meg nem határozott Curiehőmérséklete $T_{C}=863-948 \mathrm{~K}$, a magnetit $\left(\mathrm{Fe}_{3} \mathrm{O}_{4}\right)$ ferrimágneses, $T_{C}=860 \mathrm{~K}$, a FeO antiferromágneses, $T_{N}=198 \mathrm{~K}$ [23-25].

A mágneses szuszceptibilitás értéke Gouy- vagy Faraday-mágnesmérleggel határozható meg. A mágnesmérleg az $F_{x}$ erőt méri, amellyel az $m$ tömegü mintát az alkalmazott külső mágneses mező vonzza vagy taszítja.

Az M mágnesezettségü minta $d V$ térfogatelemére inhomogén mágneses térben ható $F_{x}$ erő

$$
\mathrm{F}_{\mathrm{x}}=-\mathrm{dW} / \mathrm{dx} \text {, }
$$

$W$ a mágneses kölcsönhatás energiája:

$$
\begin{aligned}
& \mathrm{W}=-\mathrm{m} \chi \int_{0}^{H} H \mathrm{dH}=-1 / 2 \mathrm{~m} \chi \mathrm{H}^{2} \\
& \mathrm{~F}_{\mathrm{x}}=1 / 2 \mathrm{~m} \chi\left(\mathrm{dH}^{2} / \mathrm{dx}\right)=\mathrm{m} \chi \mathrm{H}(\mathrm{dH} / \mathrm{dx})
\end{aligned}
$$

$\mathrm{Ha}$ az elektromágnesen átfolyó áram állandó erősségü, és a minta kellően kis $m$ tömegü, $H(d H / d x)$ jó közelítéssel állandó:

$\mathrm{H}(\mathrm{dH} / \mathrm{dx})=$ const, $\chi$ pedig az $I$ áramerősséggel arányos:

$\mathrm{m} \chi=\mathrm{kI}$

$k$ értéke meghatározható ismert minta (etalon) használatával, $k$ ismeretében pedig $\chi$ kiszámítható a mérendő mintákra nézve .

\subsubsection{Kísérleti meghatározások}

A 77-300 K hömérséklettartományban végzett kompenzációs mérésekhez Faradaymágnesmérleget használtunk (egyensúlyi állapotban a mintára ható eredő $F_{x}$ mágneses erő egyenlő a kompenzáló erővel). Az elektromágnes pólusai közé helyezett, két szálra függesztett, állítható hosszúságú kar egyik végére rögzített kvarc 
mintatartó elmozdulását mértük: a kar másik végére rögzített tükör által visszavert fénynyaláb egy beosztásos skálára esett. A hőmérsékletmérés pontossága érdekében az alacsony hömérséklet-tartományban $\mathrm{Cu}$ konstantán, a magasabban Pt-Pt-Rh (10\% $\mathrm{Rh})$ bimetál hőméröt használtunk, a feszültséget milivoltmérővel mértük. A mérleg érzékenységét diamágneses etalonokkal határoztuk meg. A pontos mérés érdekében a diamágneses ionokra és a mintatartóra korrekciót alkalmaztunk:

$$
\mathrm{I}_{\mathrm{c}}=\mathrm{I}_{\mathrm{m}}-\mathrm{I}_{\mathrm{d}}
$$

$I_{d}$ az üres, $I_{m}$ a feltöltött mintatartóval, mért áram erőssége.

A szuszceptibilitás a mérendő mintára $k$ ismeretében számított $\chi$ érték, és az (etalont jellemző) $\chi_{d}$ szuszceptibilitás összege:

$$
\chi_{\mathrm{T}}=\chi+\chi_{\mathrm{d}}
$$

A $\chi_{\mathrm{T}}{ }^{-1}=\mathrm{f}(\mathrm{T})$ függvény grafikus képe egy egyenes.

A Curie-állandó:

$$
\mathrm{C}=\mathrm{T}_{2}-\mathrm{T}_{1} /\left(1 / \chi_{\mathrm{T} 2}-1 / \chi_{\mathrm{T} 1}\right)
$$

$\chi_{\mathrm{T} 1}$ és $\chi_{\mathrm{T} 2}$ a $\mathrm{T}_{1}$ és $\mathrm{T}_{2}$ hőmérséklethez tartozó szuszceptibilitás.

A moláris Curie-állandó:

$$
\mathrm{C}_{\mathrm{M}}=\mathrm{CM}
$$

$M$ az átlagolt móltömeg.

$\mathrm{C}_{\mathrm{M}}$ segítségével kiszámítható a $\mu_{a t}$ atomos mágneses momentum:

$$
\mu_{\mathrm{at}}=2,827\left(\mathrm{C}_{\mathrm{M}} / \mathrm{a} \cdot \mathrm{x}\right)^{1 / 2}
$$

$a$ a mágneses ionok száma egy molekulában a minta összetételének megfelelő $x$ moláris frakció értéknél (egy $\mathrm{Fe}_{3} \mathrm{O}_{4}$ egység két $\mathrm{Fe}^{2+}$ iont és egy $\mathrm{Fe}^{3+}$ iont tartalmaz).

A $\mu_{a t}$ értékekböl meg lehet határozni a minta kémiai összetételében levő mágneses ion(ok) töltését. Ha ugyanis a mágneses ionnak két töltésállapota lehet $\left(\mathrm{Fe}^{2+}, \mathrm{Fe}^{3+}\right)$, az atomos mágneses momentum egyikre sem specifikus, hanem köztes értékü. A magnetit $\left(\mathrm{Fe}_{3} \mathrm{O}_{4}\right)$ esetében a $\mathrm{Fe}^{2+}$ és $\mathrm{Fe}^{3+}$ ionok mólarányának megfelelően:

$$
\mu_{\mathrm{at}}=5,26 \mu_{\mathrm{B}} \text {, }
$$

mert

$$
\begin{aligned}
& \mu_{\mathrm{at}}{ }^{2}=\mathrm{x}_{\mathrm{Fe} 2+} \mu_{\mathrm{Fe} 2+}{ }^{2}+\mathrm{x}_{\mathrm{Fe} 3+} \mu_{\mathrm{Fe} 3+}{ }^{2} \\
& \mathrm{x}_{\mathrm{Fe} 2+}=2 / 3 \text { és X } \mathrm{Fe}_{\mathrm{Fe}+}=1 / 3 \\
& \mu_{\mathrm{Fe} 3+}=5,92 \mu_{\mathrm{B}} \text { és } \mu_{\mathrm{Fe} 2+}=4,90 \mu_{\mathrm{B}}
\end{aligned}
$$

$\mu_{a t}$ a mért mágneses momentum, $\mu_{\mathrm{Fe} 2+}$ és $\mu_{\mathrm{Fe} 3+}$ a mágneses ionok elméleti mágneses momentuma a két töltésállapotban, $x_{\mathrm{Fe} 2+}$ és $x_{\mathrm{Fe} 3+}$ a mágneses ionok moláris frakciója az anyagban, $\mu_{\mathrm{B}}=9,274 \cdot 10^{-24} \mathrm{JT}^{-1}$ pedig a Bohr-magneton.

E mérések segítségével meghatározható az anyag diamágneses, paramágneses, ferromágneses, ferrimágneses vagy antiferromágneses jellege. Mágneses anyagok esetében a mérések információt adnak a mágneses ion töltésére nézve, vagy ha az két töltésállapotban is jelen van, ezek móltörtként kifejezett koncentrációjáról a mintában.

\subsubsection{Eredmények}

A mért mágneses szuszceptibilitás értékek változása az abszolút hőmérséklet reciprokának függvényében megfelel a $\mathrm{Cu}$ rie-törvénynek (1. ábra).

A fentebb ismertetett módon kiszámítottuk a Curie-állandót, ennek ismeretében a $\mu_{\mathrm{at}}$ kísérleti atomos mágneses momentumot, majd figyelembe véve $\mu_{\mathrm{Fe} 3+}$ és $\mu_{\mathrm{Fe} 2+}$ értékeit, a $\mathrm{Fe}(\mathrm{II})$ és $\mathrm{Fe}(\mathrm{III})$ moláris frakcióját az üvegekben. Az eredményeket a 2. táblázat tartalmazza.

2. táblázat. A kisérletileg meghatározott Fe(II) és $\mathrm{Fe}(I I I)$ moláris frakciók.

\begin{tabular}{|c|c|c|c|c|c|}
\hline Üvegtípus & $-\Theta_{\mathbf{p}}$ & $\mathbf{C}_{\mathbf{M}}$ & $\boldsymbol{\mu}_{\mathbf{a t}}$ & $\mathbf{x}_{\mathbf{F e} 3+}$ & $\mathbf{x}_{\mathbf{F e} 2+}$ \\
\hline R20 & 5 & 0.8819 & 5.49 & 0,48 & 0,52 \\
\hline R21 & 6 & 0.8897 & 5.44 & 0,56 & 0,44 \\
\hline R22 & 7 & 0.8784 & 5.41 & 0,54 & 0,46 \\
\hline R23 & 12 & 1.3307 & 5.76 & 0,62 & 0,38 \\
\hline R24 & 13.5 & 0.5413 & 5.2 & 0,42 & 0,58 \\
\hline
\end{tabular}




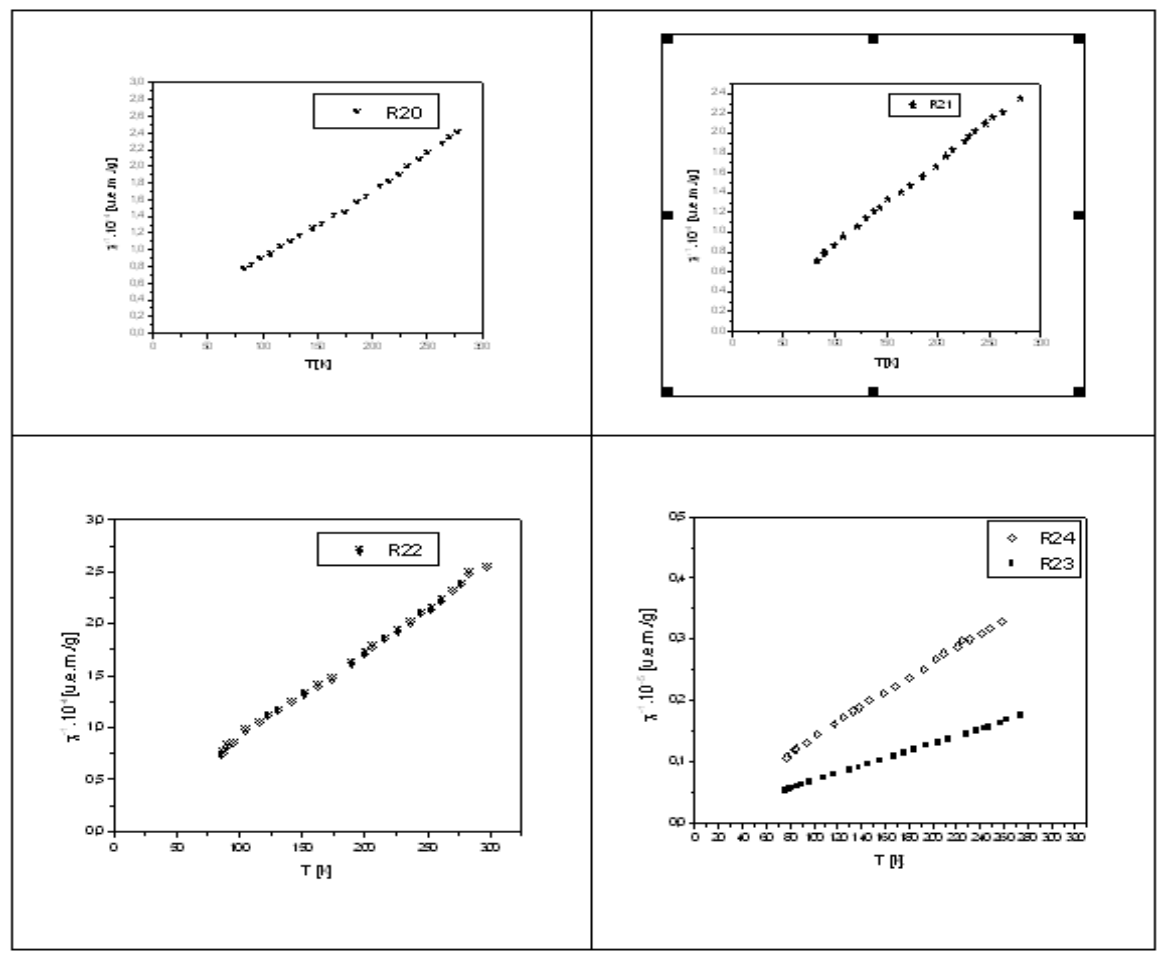

1. ábra. $\chi_{T}$ változása $(1 / T)$ függvényében.

A Fe két különböző oxidációs állapotának megfelelő moláris frakció értékek az R20, R21 és R22 üvegek esetében megfelelnek az elvárásoknak. Megállapítható ugyanakkor, hogy az üvegolvadékban beálló redox egyensúly függ a $\mathrm{SiO}_{2} / \mathrm{B}_{2} \mathrm{O}_{3}$ aránytól.

Az R24 minta esetében az eredmény az olvasztási körülményekkel magyarázható: a levegő jelenlétében történő olvasztás során (3 óra $1450{ }^{\circ} \mathrm{C}$-on) a $\mathrm{Fe}$ (II) könnyen oxidálódhat. Annak magyarázata, hogy hasonló olvasztási körülmények között az R23 minta kezdeti $\mathrm{Fe}_{2} \mathrm{O}_{3}$ tartalma jelentős mértékban redukálódott, valószínüleg a magas hőmérsékleten termodinamikailag kedvezményezett $\mathrm{Fe}(\mathrm{II})$ állapot. A redox reakció során a $\mathrm{Fe}_{2} \mathrm{O}_{3}$ részben redukálódik, mivel azonban a felszabaduló $\mathrm{O}_{2}$ gáz távozik a rendszerből, a lehülés ideje alatt a visszaoxidálódás nem következik be: a magas hőmérsékletü redox egyensúly az üveg kiöntésekor „belefagy” az anyagba.

\subsubsection{FT-IR mérések}

\subsubsection{Kisérleti körülmények}

Az FT-IR spektrumokat FTIR JASCO 6100 spektrométerrel vettük fel, standard $\mathrm{KBr}$ pasztillákon, $2 \mathrm{~cm}^{-1}$ felbontással, a $4000-400 \mathrm{~cm}^{-1}$ közötti IR tartományban. $\mathrm{Az}$ adatfeldolgozáshoz (spektrumábrázolás, dekonvolúció) Origin 8 programot használtunk.

\subsubsection{Eredmények}

A rendezetlen anyagi rendszerek IR spektrumában a szerkezeti egységek egymáshoz közel eső, egymást átfedő abszorpciós maximumai nehezen értékelhető széles abszorpciós sávokat generálnak 
(konvolúció). A boroszilikát és aluminoboroszilikát üvegek esetében jelentős a $\mathrm{BO}_{3}, \mathrm{~B}_{2} \mathrm{O}_{6}$ (boroxol gyürü), $\mathrm{BO}_{4}, \mathrm{SiO}_{4}$ egységek rezgési módusainak megfelelö IR abszorpciók átfedése. Az FTIR spektrumok analízisére alkalmazott Fourierdekonvolúciós eljárás segítségével (dekonvolúció: a konvoluált széles sávok komponensekre bontása) a sávszélességek csökkenthetők, az egymáshoz közel eső, eredetileg részleges vagy teljes átfedésben levő spektrumvonalak különválaszthatók, a felbontás javul. A dekonvoluált spektrum minősége természetesen függ a mért spektrum minőségétöl. A dekonvolúciós adatok felhasználásával szimulált IR spektrumgörbe jó illeszkedés esetén $\left(R^{2} \geq 0.995\right.$ hibahatár felett) teljesen ráfekszik a kísérleti görbére [26-28].

A vizsgált üvegeken felvett FT-IR spektrumok a 2. ábrán láthatók.

A felületükön erősen kristályosodó R22 és R23 üvegek esetében az esetleges szerkezeti különbségek megállapításának érdekében felvettük mind a belső (üveges), mind a külső (kristályos) fázis (R22a és R22b, illetve R23a és R23b) spektrumát (a teljes FT-IR spektrumokat bemutató 2. ábrán csak az R22a és R23a üveges fázisok spektruma jelenik meg).

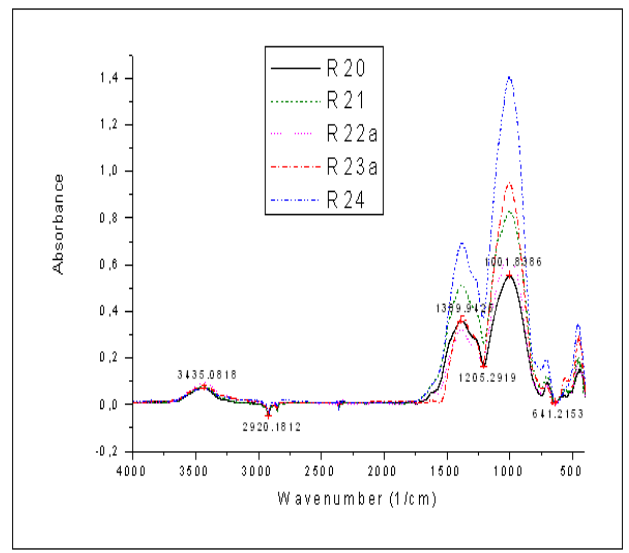

2. ábra. A vizsgált üvegek FT-IR spektruma.
A teljes spektrumokon megjelenő elnyelési sávok alapján, dekonvolúciós analizis hiányában a következö általános hozzárendelések tehetők: [29-31]

$-3435 \mathrm{~cm}^{-1} \quad \mathrm{O}-\mathrm{H}$

$-1600 \mathrm{~cm}^{-1} \quad \mathrm{O}-\mathrm{H}$

$-1390 \mathrm{~cm}^{-1} \quad$ trigonális $\mathrm{BO}_{3}$

$-1205 \mathrm{~cm}^{-1} \quad \mathrm{~B}^{3}-\mathrm{O}\left(\mathrm{B}^{3}\right)$ csoportok

$-1000 \mathrm{~cm}^{-1}$ körül (a nagy intenzitású, domináns abszorpciós sáv) a tetraéderes, lineárisan kapcsolódó $\mathrm{BO}_{4}$ és $\mathrm{SiO}_{4}$ egységek szimmetrikus és aszimmetrikus $\mathrm{B}-\mathrm{O}-\mathrm{B} ; \quad \mathrm{Si}-\mathrm{O}-\mathrm{Si} ; \quad \mathrm{O}-\mathrm{Si}-\mathrm{O} ; \quad \mathrm{B}-\mathrm{O}-\mathrm{Si}$ vegyértékrezgései és deformációs rezgései

$-641 \mathrm{~cm}^{-1} \quad$ tetraborát

$-778 \mathrm{~cm}^{-1} \quad$ boroxol gyürü „lélegzése”

$-460-470 \mathrm{~cm}^{-1}$ különálló $\mathrm{BO}_{4}$ egységek vegyértékrezgései.

Mivel a boroszilikát és aluminoboroszilikát üvegek legfontosabb IR elnyelési spektrumtartománya a $1500-400 \mathrm{~cm}^{-1}$ közötti, az FT-IR spektrumok dekonvolúcióját ebben a hullámszám-tartományban végeztük el. A dekonvolúciós analízis eredményei a 3. ábrán láthatók. A felületükön kristályosodó minták kristályos és üveges fázisának szerkezeti különbözőségéről az R22a és R22b spektrumok dekonvolúciós adatainak összehasonlításával nyerhetünk képet.

A felbontás következtében láthatóvá vált abszorpciós frekvenciákat és a megfelelö hozzárendeléseket a 3. táblázat tartalmazza (a táblázatban csak az R22 és R23 minták üveges fázisára vonatkozó adatok jelenítettük meg).

Az $550 \mathrm{~cm}^{-1}$ körül minden minta spektrumában jelentkező elnyelési sáv részben a rácsszerkezet deformációs rezgéseinek, részben a vizsgált üvegek által tartalmazott $\mathrm{FeO}_{4}$ csoportoknak $\left(\mathrm{Fe}^{2+}\right)$ tulajdonítható. A 690-710 $\mathrm{cm}^{-1}$ tartományban, illetve a 920 $\mathrm{cm}^{-1}$-nél megjelenő sávok elsősorban a híd helyzetű $\mathrm{O}$ atomok deformációs rezgéseinek feleltethetők meg ( $\mathrm{Si}-\mathrm{O}-\mathrm{Si}, \mathrm{B}-\mathrm{O}-\mathrm{B}$, 
Si-O-B). $1010 \mathrm{~cm}^{-1}$ körül jelentkeznek a rácsban kapcsolódó $\mathrm{SiO}_{4}$ és $\mathrm{BO}_{4}$ egységek aszimmetrikus vegyértékrezgéseinek megfelelő sávok. Az 1270-1275, 1375-1390 és $1480 \mathrm{~cm}^{-1}$ körüli abszorbció föleg a különféle borátcsoportokat összekapcsoló, híd helyzetủ B-O vegyértékrezgéseitől származik.

Az R22a - R22b és R23a - R23b minták spektrumfeldolgozásából származó adatokat a 4. táblázatban foglaltuk össze.

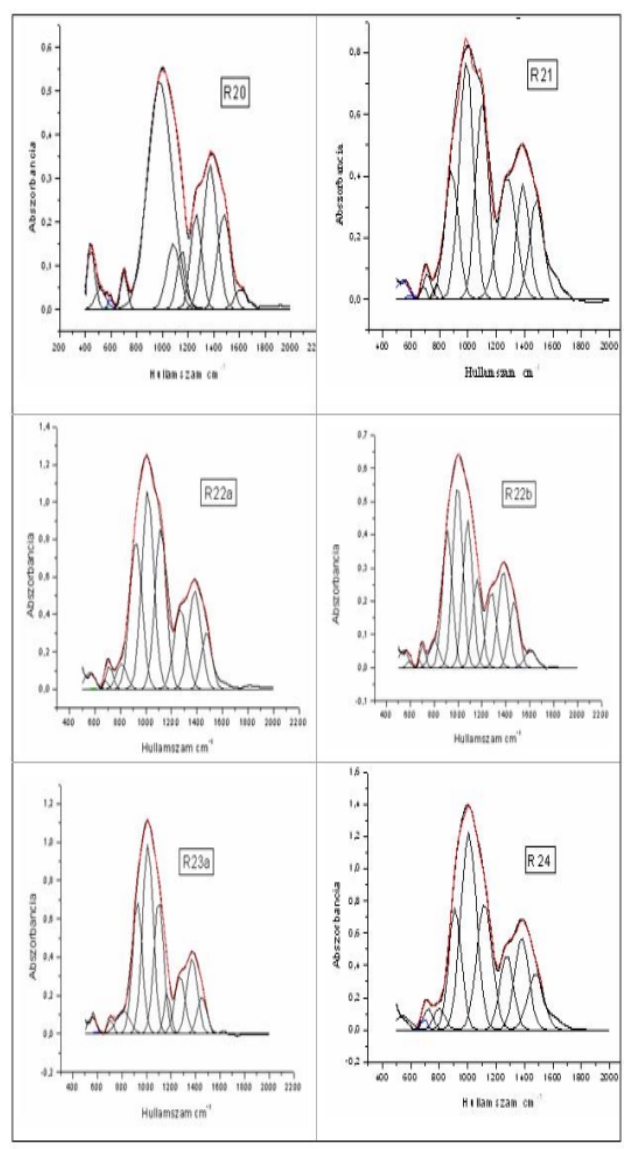

3. ábra. Az FT-IR spektrumok dekonvolúciója az 1500-400 $\mathrm{cm}^{-1}$ közötti tartományban (R20R24; az R22 minta esetében az ábrán látható az R22a üveges és R22b kristályos fázis spektrumfelbontása is).
3. táblázat. $A z R 20-R 24$ üvegek FT-IR spektrumának dekonvolúciója során megjelenö abszorpciós sávok és a megfelelö hozzárendelések ( $v, \delta$ : vegyértékrezgés, deformációs rezgés, A: görbe alatti terület, a sávintenzitást jellemzi)

\begin{tabular}{|c|c|c|c|c|c|c|c|c|c|c|c|}
\hline \multicolumn{2}{|c|}{$\mathrm{R} 20$} & \multicolumn{2}{|c|}{$\mathrm{R} 21$} & \multicolumn{2}{|c|}{$\mathrm{R} 2 \mathrm{ia}$} & \multicolumn{2}{|c|}{$\mathrm{R} 23 \mathrm{a}$} & \multicolumn{2}{|c|}{ R24 } & \multirow{3}{*}{\multicolumn{2}{|c|}{ Hozzirendeles }} \\
\hline $\mathrm{SO}_{2}$ & $\mathrm{~B}_{2} \mathrm{O}_{3}$ & \multirow{2}{*}{\multicolumn{2}{|c|}{$\begin{array}{c}\mathrm{SiO}_{2} \mathrm{~B}_{2} \mathrm{O}_{3} \\
\mathrm{Fe}^{3+}: \mathrm{Fe}^{2+} \\
1: 1\end{array}$}} & \multicolumn{2}{|c|}{$\mathrm{SiO}_{2} \vartheta_{2} \mathrm{~B}_{2} \mathrm{O}$} & \multicolumn{2}{|c|}{$\mathrm{Si}_{2} \mathrm{O}_{2} \mathrm{E}_{2} \mathrm{O}_{3}$} & \multicolumn{2}{|c|}{$\mathrm{SO}_{2}{ }_{2} \gg \mathrm{B}_{2} \mathrm{O}_{3}$} & & \\
\hline $\begin{array}{r}\mathrm{Fe}^{3+} \\
1\end{array}$ & & & & \multicolumn{2}{|c|}{$\begin{array}{c}\mathrm{Fe}^{3+}: \mathrm{Fe}^{2+} \\
1: 1\end{array}$} & \multicolumn{2}{|c|}{$\mathrm{Fe}^{3+}$} & \multicolumn{2}{|c|}{$\mathrm{Fe}^{2+}$} & & \\
\hline \multicolumn{2}{|c|}{$\mathrm{R}^{2}=0.998$} & \multicolumn{2}{|c|}{$R^{2}=0.992$} & \multicolumn{2}{|c|}{$\mathrm{R}^{3}=0.996$} & \multicolumn{2}{|c|}{$R^{2}=0.098$} & \multicolumn{2}{|c|}{$R^{2}=0,099$} & \multirow{2}{*}{$\begin{array}{l}\text { Szilikát } \\
\text { csopoutol }\end{array}$} & \multirow{2}{*}{$\begin{array}{c}\text { Borat } \\
\text { copopotolok }\end{array}$} \\
\hline $\mathrm{cm}^{1}$ & A & $\mathrm{cm}^{-1}$ & A & $\mathrm{cm}^{-1}$ & A & $\mathrm{cm}^{-1}$ & A & $\mathrm{cm}^{-1}$ & A & & \\
\hline & 9,5 & & & & & & & & & $\mathrm{~S} 1-0-\mathrm{S} 1(0)$ & \\
\hline 510 & 3,8 & & & & & & & & & & $\mathrm{Fe}^{3+}$ \\
\hline 571 & 0,4 & 540 & 6,3 & 560 & 9,1 & 555 & 7,8 & 545 & 10,7 & gởunus szerk & \\
\hline & & 689 & 2,1 & 685 & 2,2 & 686 & 0,3 & 694 & 3,2 & & $\mathrm{~B} \cdot 0 \cdot \mathrm{B}(\delta)$ \\
\hline 703 & 5,5 & 714 & 5,9 & 712 & 8,7 & $70 ?$ & 4,2 & 721 & 11,4 & & $\mathrm{~B} \cdot 0 \cdot \mathrm{E}(\mathrm{v}, \delta)$ \\
\hline & & 781 & 2,8 & 807 & 13,9 & 810 & 17,1 & 801 & 13,0 & S1-0.[NE] $(\delta)$ & borozol \\
\hline 930 & 66,5 & 885 & 50,1 & 920 & 96,3 & 927 & 69,2 & 912 & 86,2 & \$1-0.[NB],00 & B. $0 \cdot \mathrm{E}(\delta)$ \\
\hline 1034 & 49,3 & 990 & 97,0 & 10.4 & 125,4 & 1012 & 105,9 & 1008 & 169,0 & S1-0.[NE] & B. $0 . S(V)$ \\
\hline 1127 & 32,1 & 1100 & 73,3 & 1115 & 97,2 & 1100 & 70,3 & 1120 & 107,3 & S1-0.[NB] & $B^{4} \cdot 0 \cdot 5^{4}(\mathrm{v})$ \\
\hline & & & & & & 1169 & 14,6 & & & S1-0[NB],Q3 & $B^{4}-0\left(B^{3}\right)$ \\
\hline 1270 & 31,0 & 1275 & 64,3 & 1270 & 53,4 & 1273 & 32,0 & 1275 & 55,3 & & $B^{3} \cdot O\left(B^{3}\right)(n)$ \\
\hline 1381 & 39,5 & 1389 & 41,9 & 1392 & 64,3 & 1372 & 43,0 & 1381 & 72,1 & & $\mathrm{~B}^{\prime} \cdot O\left(\mathrm{~B}^{\prime}\right)(\mathrm{T})$ \\
\hline 1482 & 26,3 & 1486 & 40,5 & 1475 & 30,8 & 1453 & 18,5 & 1480 & 48,5 & & $\mathrm{~B}^{\prime} \cdot O\left(\mathrm{~B}^{\prime}\right)(\mathrm{T})$ \\
\hline
\end{tabular}

4. táblázat. Hasonlóságok és különbségek az R22 és R23 minták üveges és kristályos fázisának IR elnyelése esetében (A arányos a sávintenzitással)

\begin{tabular}{|c|c|c|c|c|c|c|c|}
\hline \multicolumn{2}{|c|}{$\mathrm{R} 22 \mathrm{a}$} & \multicolumn{2}{|c|}{ R22b } & \multicolumn{2}{|c|}{ R23a } & \multicolumn{2}{|c|}{ R23b } \\
\hline \multicolumn{2}{|c|}{ belsô, üveges } & \multicolumn{2}{|c|}{ külsô, kristályos } & \multicolumn{2}{|c|}{ belsố, üveges } & \multicolumn{2}{|c|}{ külsô, kristályos } \\
\hline \multicolumn{4}{|c|}{$\begin{array}{c}\mathrm{SiO}_{2}>\mathrm{B}_{2} \mathrm{O}_{3} \\
\mathrm{Fe}^{3+}: \mathrm{Fe}^{2+}=1: 1\end{array}$} & \multicolumn{4}{|c|}{$\begin{array}{c}\mathrm{SiO}_{2}>>\mathrm{B}_{2} \mathrm{O}_{3} \\
\mathrm{Fe}^{3+}\end{array}$} \\
\hline \multirow[t]{2}{*}{$\mathrm{cm}^{-1}$} & A & $\mathrm{cm}^{-1}$ & A & $\mathrm{cm}^{-1}$ & A & $\mathrm{cm}^{-1}$ & A \\
\hline & & & & & & 525 & 6,5 \\
\hline 560 & 9,1 & 540 & 5,2 & 555 & 7,8 & 564 & 1,3 \\
\hline 592 & 0,2 & 591 & 1,0 & 590 & 0,5 & 580 & 3,0 \\
\hline 685 & 2,2 & 680 & 0,7 & 686 & 0,3 & 698 & 0,5 \\
\hline 712 & 8,7 & 703 & 3,7 & 707 & 4,2 & 705 & 3,2 \\
\hline 807 & 13,9 & 800 & 8,7 & 810 & 17,1 & 778 & 7,0 \\
\hline 920 & 96,3 & 910 & 41,6 & 927 & 69,2 & 907 & 62,0 \\
\hline 1014 & 125,4 & 996 & 57,7 & 1012 & 105,9 & 1011 & 115,3 \\
\hline \multirow[t]{2}{*}{1115} & 97,2 & 1080 & 45,5 & 1100 & 70,3 & 1123 & 66,0 \\
\hline & & 1160 & 26,8 & 1169 & 14,6 & & \\
\hline 1270 & 53,4 & 1278 & 24,4 & 1273 & 32,0 & 1277 & 25,6 \\
\hline 1382 & 64,3 & 1379 & 32,0 & 1373 & 43,0 & 1374 & 38,6 \\
\hline \multirow[t]{2}{*}{1475} & 30,8 & 1470 & 19,9 & 1453 & 18,5 & 1457 & 17,5 \\
\hline & & 1604 & 6,3 & & & & \\
\hline \multicolumn{2}{|c|}{$\mathrm{R}^{2}=0.996$} & \multicolumn{2}{|c|}{$\mathrm{R}^{2}=0.998$} & \multicolumn{2}{|c|}{$\mathrm{R}^{2}=0.998$} & \multicolumn{2}{|c|}{$\mathrm{R}^{2}=0,999$} \\
\hline
\end{tabular}

Mint a 4. táblázat adataiból kitünik, az azonos elemi összetételü, de eltérő rendezettségü szerkezettel rendelkező fázisok IR spektrumában a jelentősebb elnyelési sávok gyakorlatilag azonos frekvenciáknál (vagy csak kissé eltolódva) jelentkeznek, a szer- 
kezeti különbségek következtében azonban a sávintenzitások elég nagymértékben különbözhetnek. Ennek pontosabb jellemzésére a röntgen-pordiffrakciós adatok (mikroszerkezeti szempontból való) feldolgozása adhat lehetőséget.

\subsubsection{Röntgen pordiffraktometria és opti- kai mikroszkópia}

\subsubsection{Kísérleti körülmények}

Az egyenletes vastagságú vékony rétegben a mintatartó felületére rögzített, keményacél golyósmalomban finom porrá örölt minták XRD vizsgálatához standard Bruker D8 Advance diffraktométert használtunk, a következő müszaki paraméterek mellett: monokromatikus koherens $\mathrm{Cu}-\mathrm{K}_{\alpha}$ beeső sugárnyaláb, mérési tartomány: $2 \theta=$ $5-90^{\circ}, \Delta 2 \theta=0.01^{\circ}$, sugárforrás: $45 \mathrm{kV}$-on $45 \mathrm{~mA}$ árammal fütött $\mathrm{Cu}$ anódos röntgencső, Ni monokromátor, Soller rések, spektráltiszta $\alpha-\mathrm{Al}_{2} \mathrm{O}_{3}$ belső standard. A detektálható kristályfázisok meghatározása a MATCH! pordiffrakciós fázisazonosító programmal történt, az IUCr/COD/AMCSD referencia adatbázis adatainak felhasználásával [32].

A minták $30 \mu \mathrm{m}$ vastagságú vékonycsiszolatáról 100×, 200× és $400 \times$ nagyítással készült mikroszkópos képeket digitális kamerával ellátott Olympus BX 41 típusú mikroszkóppal vettük fel, transzmissziós üzemmódban, polarizáció nélkül.

\subsubsection{Eredmények}

Az R20-R24 mintán felvett röntgendiffraktogramokat és az ezekhez társított mikrofotókat a 4. ábrán mutatjuk be, a kivált kristályos fázisokra vonatkozó XRD adatatokat az 5. táblázatban foglaltuk öszsze. R22 és R23 esetében mindkét helyen csak az üveges fázisra vonatkozó eredményeket jelenítettük meg.

A mikrofelvételek alapján a vizsgált üvegek mindegyike kristályosodik (legnagyobb mértékben a kiinduló oxidkeveréké- ben kizárólag $\mathrm{Fe}_{2} \mathrm{O}_{3}$ adalékot tartalmazó R23, legkevésbé a $\mathrm{FeO}$ adalékolt R24). A kristályos fázis XRD módszerrel azonosított fő komponense a tüszerü kristályokként megjelenő hematit. A kutatás által célzott magnetitet nagyobb mennyiségben csak az R22 mintában detektáltuk. Az R24 minta üveges szerkezetében a diffraktogramon meg sem jelenő, egyenletes eloszlású (egyelöre azonosítatlan) nanokristályos fázis mellett feltehetően egy láncszilikát látható.

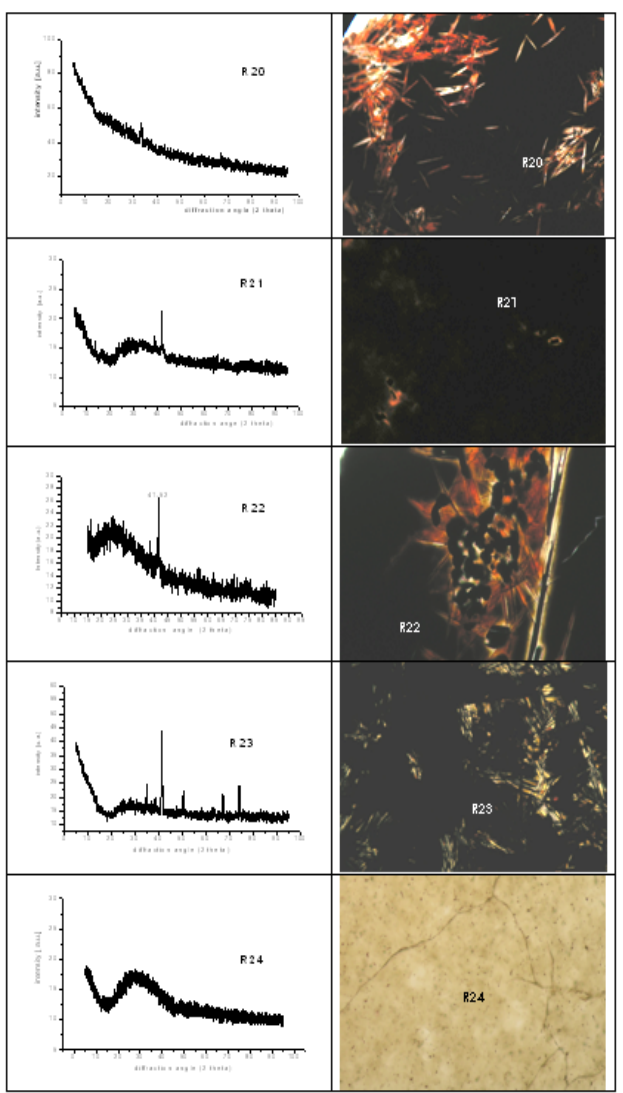

4. ábra. Az üvegek röntgendiffraktogramja és 200× nagyítású mikrofotója

$\mathrm{Az}$ optikai mikroszkópos vizsgálat eredményei megerősítik, jól kiegészítik a röntgendiffrakciós adatokat.

Diffraktogramja alapján az $R 20$ minta csaknem teljesen üveges, alig kristályoso- 
dott, az azonosítható kristályos fázis a tüszerü krisztallitokként megjelenő kvarc, kvarcit.

Az R21 szerkezete csaknem teljesen rendezetlen, a jellegzetes üveges fázis jól láthatóan domináns. A kiinduló oxidkeverék összetétele közel áll az R20 mintáéhoz, a $\mathrm{SiO}_{2}$ mennyiségének a $\mathrm{B}_{2} \mathrm{O}_{3}$ számlájára való kismértékü növelése következtében azonban az olvadék dermedése során kristályos fáziselválás lép fel. Mint az optikai mikroszkópos vizsgálat mutatja, a kivált hematit koncentrációja nem túl jelentős, krisztallitmérete viszonylag nagy.

Az. R22 minta az előbbi mintáknál valamivel kristályosabb. A minta összetételében a $\mathrm{B}_{2} \mathrm{O}_{3}$ hátrányára tovább növelve a $\mathrm{SiO}_{2}$ mennyiséget, a hematit mellett kristályos fázisként valamennyivel jelentősebb mennyiségben megjelenik a magnetit. A krisztallitok mérete ez esetben is túl nagy. A viszonylag zajos diffraktogram oka valószínüleg a méréshez használt minta szükös mennyisége.

5. táblázat. $A z R 20-R 24$ minták XRD adatai

\begin{tabular}{|c|c|c|c|c|}
\hline Minta & $2 \theta$ (fok) & $\mathbf{d}(\AA)$ & I (a.u.) & $\begin{array}{l}\text { Azonositott } \\
\text { ásványfázis }\end{array}$ \\
\hline \multirow{2}{*}{ R20 } & 33.42 & 3.11 & - & \multirow{2}{*}{$\operatorname{kvarc}\left(\mathrm{SiO}_{2}\right)$} \\
\hline & 67.22 & 1.62 & - & \\
\hline \multirow{2}{*}{ R21 } & 41.73 & 2.51 & - & magnetit $\left(\mathrm{Fe}^{2+} \mathrm{Fe}_{2}{ }^{3+} \mathrm{O}_{4}\right)$ \\
\hline & 38.75 & 2.70 & - & hematit $\left(\alpha-\mathrm{Fe}_{2} \mathrm{O}_{3}\right)$ \\
\hline \multirow{3}{*}{$\mathrm{R} 22$} & 38.36 & 2.72 & 19 & hematit \\
\hline & 41.52 & 2.52 & 27 & magnetit $\left(\mathrm{Fe}^{2+} \mathrm{Fe}_{2}{ }^{3+} \mathrm{O}_{4}\right)$ \\
\hline & 73.85 & 1.49 & 14 & magnetit $\left(\mathrm{Fe}_{3} \mathrm{O}_{4}\right)$ \\
\hline \multirow{8}{*}{$\mathrm{R} 23$} & 35.00 & 2.98 & 25 & magnetit \\
\hline & 38.75 & 2.70 & 19 & hematit \\
\hline & 41.35 & 2.53 & 40 & magnetit \\
\hline & 50.40 & 2.10 & 22 & magnetit \\
\hline & 62.80 & 1.72 & 16 & magnetit \\
\hline & 63.70 & 1.70 & 15 & magnetit \\
\hline & 67.15 & 1.62 & 20 & kvarc \\
\hline & 74.10 & 1.48 & 22 & magnetit \\
\hline $\mathrm{R} 24$ & & 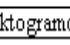 & ristán & sfázis nem d \\
\hline
\end{tabular}

Az R23 minta kiinduló oxidkeveréke adalékként csak Fe(III)-oxidot tartalmazott. Az olvasztás körülményei között az olvasztási hőmérsékleten beálló redox egyensúlynak megfelelöen a $\mathrm{Fe}^{3+}$ csaknem felerészben redukálódott. A keletkezett, erősen kristályos üveg domináns kristályfázisa a magnetit, mellette kevés hematittal.

Mikrofotói alapján az R24 minta nanokristályos, diffraktogramja alapján azonban tisztán üveges szerkezetü. Az eltérés magyarázata a krisztallitok nagyon kis átlagos mérete és alacsony koncentrációszintje (az XRD mérések érzékenysége $1 \ldots 3 \%$ ). A kristályos fázis összetételéről rgyelőre nincseknek adataink.

\section{Következtetések}

Az oxidüvegek esetében az időtállóságot, a gyakorlatban való alkalmazhatóságot elsősorban a szerkezeti, termikus és hidrolitikus stabilitás határozza meg. A felsorolt jellemzők szoros összefüggésben vannak az üvegösszetétel és üvegszerkezet homogénségével és a kristályosodási hajlammal. A mágneses üvegek esetében emellett elsődlegesen fontos az üvegmátrixban kiváló, a mágneses tulajdonságokat biztosító krisztallitok egyenletes eloszlása és átlagos mérete. Ez utóbbira nézve meghatározó lehet az üveghez adalékolt átmeneti fémek oxidációs állapota, amely a fémionok koordinációs környezete révén közvetlenül befolyásolja a szerkezetet és a kristálykiválást [33,34]. A jelen esetben az üvegszerkezet jelentősen függ az üveg összetételében levő vas oxidációs állapotától és az ezáltal meghatározott lokális koordinációtól.

$\mathrm{Az}$ itt bemutatott mérési eredmények alapján megállapítható, hogy a dolgozatban tárgyalt üvegek szerkezeti és kristályosodási jellemzőinek változása többnyire az elvárt módon követi a szakirodalmi adatoknak megfelelő trendet. 
A mágneses szuszceptibilitás adatok alapján megállapítható ugyanakkor, hogy az olvasztás során beálló Fe(II)-Fe(III) egyensúlyt nem csak a Fe koncentráció és a kezdeti $\mathrm{Fe}_{2} \mathrm{O}_{3} / \mathrm{FeO}$ arány, hanem a fö rácsképző oxidok $\left(\mathrm{SiO}_{2}, \mathrm{~B}_{2} \mathrm{O}_{3}\right)$ kezdeti mennyiségének aránya is erösen befolyásolja.

Az FT-IR és az optikai mikroszkópos vizsgálat által is alátámasztott XRD adatok szerint a kiinduló oxidösszetétel változásának befolyása az üvegek devitrifikációjára, lokális szerkezetére (és általában véve a szerkezeti rendezettségre) általában megfelel az irodalmi adatok alapján várhatónak [35-37].

\section{Szakirodalmi hivatkozások}

[1] Divya, P.V., Kumar, V.: Crystallization Studies and Properties of $\left(\mathrm{Ba}_{1-x} \mathrm{Sr}_{x}\right) \mathrm{TiO}_{3}$ in Borosilicate Glass. Journal of the American Ceramic Society, 90(2), 2007, 472-476.

[2] Kumar, D. és mások: Preparation and Dielectric Characterization of Ferroelectric $\left(\mathrm{Pb}_{x} \mathrm{Sr}_{1-x}\right) \mathrm{TiO}_{3}$ Glass Ceramics Doped with $\mathrm{La}_{2} \mathrm{O}_{3}$, Applied Physics Letters, 89(11), 2006, 12908-12910.

[3] Yadav, A. és mások: Crystallization Kinematics and Dielectric Behavior of (Ba,Sr) $\mathrm{TiO}_{3}$ Borosilicate Glass Ceramics. New Journal of Glass and Ceramics, 2(3), 2012, 126-131.

[4] Senthil Murugan, G. és mások: Nonlinearoptic and ferroelectric behavior of lithium borate-strontium bismuth tantalate glassceramic composite. Applied Physics Letters, 78(25), 2001, 4019-4021.

[5] Yao, K. és mások: Effects of glass elements on the structural evolution of in situ grown ferroelectric perovskite crystals in sol-gel derived glass-ceramics. Journal of materials research, 12(4), 1997, 1131-1140.

[6] Kaewkhao, J. és mások: Structural and magnetic properties of glass doped with iron oxide. Journal of Physics: Conference Series 266(1), 2011, 012012, 5 pp.

[7] Abdel-Hameed, S.A. és mások: Preparation and Characterization of Magnetic Glass Ceramics Derived from Iron Oxides Bearing Rolling Mill Scales Wastes. Nano Research \& Applications, 1(6), 2015, 1-11.
[8] Malakhovskii, A.V. és mások: Magnetic and magneto-optical properties of oxide glasses containing $\mathrm{Pr}^{3+}, \mathrm{Dy}^{3+}$ and $\mathrm{Nd}^{3+}$ ions. Journal of magnetism and magnetic materials, 263(1), 2003, 161-172.

[9] Pop, L. és mások: Magnetic Behaviour of Some Oxide Glasses Doped With Rare Earth Ions. In AIP Conference Proceedings, S. Ali Cetin and I. Hikmet eds., 899(1), 2007, 591.

[10] Haro-González, P. és mások: Characterization of $\mathrm{Er}^{3+}$ and $\mathrm{Nd}^{3+}$ doped Strontium Barium Niobate glass ceramic as temperature sensors. Optical Materials 33(5), 2011, 742745.

[11] Singh, D. és mások: Optical and structural properties of $\mathrm{ZnO}-\mathrm{PbO}-\mathrm{B}_{2} \mathrm{O}_{3}$ and $\mathrm{ZnO}$ $\mathrm{PbO}-\mathrm{B}_{2} \mathrm{O}_{3}-\mathrm{SiO}_{2}$ glasses. Journal of Physics: Condensed Matter, 20(7), 2008, 075228, 6 pp.

[12] Balu, L. és mások: Effect of $\mathrm{ZnO}$ on Physical, Structural and Mechanical Properties of $\mathrm{B}_{2} \mathrm{O}_{3}-\mathrm{Na}_{2} \mathrm{O}-\mathrm{ZnO}$ Glasses, IOSR Journal of Applied Physics, 8(6), 2016, 140-146.

[13] Bahra, N.H. és mások: Effect of Different Concentrations of Doped Rare Earth Element on Borate-Silica Oxide Glass Structure. Journal of Optoelectronics and Biomedical Materials, 7(2), 2015, 47-52.

[14] Sasmal, N. és mások: Influence of $\mathrm{Ce}, \mathrm{Nd}$, $\mathrm{Sm}$ and $\mathrm{Gd}$ oxides on the properties of alkaline-earth borosilicate glass sealant. Journal of Asian Ceramic Societies, 4(1), 2016, 2938.

[15] Coey, J.M.D. és mások: Introduction to magnetic oxides. In Functional Metal Oxides: New Science and Novel Applications, Ogale, S.B., Venkatesan, T.V., Blamire, M.G., Eds., Wiley-VCH Publ., 2013, 1-49.

[16] Schüppel, W. és mások: Magnetic Oxide Particles Prepared by Glass Crystallization. In Scientific and Clinical Applications of Magnetic Carriers. In Scientific and Clinical Applications of Magnetic Carriers, Häfeli,U., Schütt, W., Teller, J., Zborowski, M., Eds., Springer US, 1997, 109-115.

[17] Edelman, I. Kliava, J.: Oxide glasses with magnetic nanoparticles: transparent magnets (Faraday rotation and electron magnetic resonance studies). physica status solidi (b), 246(10), 2009, 2216-2231. 
[18] Winterstein, A. és mások: Magnetic and magneto-optical quenching in $\left(\mathrm{Mn}^{2+}, \mathrm{Sr}^{2+}\right)$ metaphosphate glasses. Optical Materials Express, 3(2), 2013, 184-193.

[19] Romero-Perez, M. és mások: "Magnetic properties of glasses with high iron oxide content", Materials research bulletin, 36(7), 2001, 1513-1520.

[20] Atkins, P. de Paula, J.: Mechanical, electrical and magnetic properties of solids, , Magnetic properties, In Atkins' Physical Chemistry, 10th Ed., Oxford University Press, 2014, 768-771.

[21] Preuss, K.: How do we measure magnetic properties? Instrumentation and techniques. http://www.chemistry.uoguelph.ca/educmat/c $\mathrm{hm} 710 /$, 7.4., 2015, 6pp.

[22] https://www.tf.uni-

kiel.de/matwis/amat/elmat_en/kap_4/advance d/t4_1_3.html.

[23] Zhang, P. és mások: Magnetic properties of FeO: a DFT+DMFT study, In APS March Meeting 2014, Abstract \#G54.014, 2014APS.MARG54014Z.

[24] https://magwiki.wikispaces.com/Maghemite

[25] https://magwiki.wikispaces.com/Magnetite

[26] Griffiths, P.R. és mások: Curve Fitting and Fourier Self-Deconvolution for the Quantitative Representation of Complex Spectra. In Computer-enhanced Analytical Spectroscopy, Meuzelaar, H.L.C., Isenhour, T.L., Eds., Plenum Press: New York, 1989, 29-54.

[27] Barth, A.: Fine-structure enhancement assessment of a simple method to resolve overlapping bands in spectra. Spectrochimica Acta A 56(6), 2000, 1223-1232.

[28] Gautam, C. és mások: A Review on Infrared Spectroscopy of Borate Glasses with Effects of Different Additives. ISRN Ceramics, 2012, Article ID 428497, 17 pp.

[29] Yahya, G.A.: Studies on Some LithiumBorate Glasses Containing Iron and Copper. Turkish Journal of Physics, 27, 2003, 255262.
[30] Silim, H.A.: Composition Effect on Some Physical Properties and FTIR Spectra of Alumino-Borate Glasses Containing Lithium, Sodium, Potassium and Barium Oxides. Egyptian. Journal of Solids, 29(2), 2006, 293302.

[31] Azooz, M.A. és mások: Characterization of bioactivity in transition metal dopedborosilicate glasses by infrared reflection and dielectric studies. Indian Journal of Pure and Applied Physics, 46(12), 2008, 880-888.

[32] http://www.crystalimpact.com/match/.

[33] Rose, P.B. és mások: Crystallisation within simulated high level waste borositicate glass. In Scientific Basis for Nuclear Waste Management XXVIII, Hanchar, J.M., StroesGascoyne, S., Browning, L., Eds., Materials Research Society Symposia Proceedings, Vol. 824, MRS Warrendale PA, USA, 2004, 321326.

[34] Mishra, R.K. és mások: Structural aspects of barium borosilicate glasses containing thorium and uranium oxides. Nuclear Materials, 359(12), 2006, 132-138.

[35] Sandu, V. és mások: Nanostructured Ferrite Formation in Borosilicate Glass. In Multi-Functional Materials and Structures II, Yin, Y., Wang, X., Eds., Trans Tech Publications, Switzerland, Advanced Materials Research Vol. 79-82, 2009, 445448.

[36] Harizanova, R. és mások: Phase Separation and Crystallisation in High Iron Containing Borosilicate Glasses. In Functional Properties of Nanostructured Materials, R. Kassing, P. Petkov, W. Kulisch, C. Popov, Eds., Springer, Dordrecht, Nato Science Series, Vol. 223, 2006, 169-172.

[37] Harizanova, R. és mások: Microstructures formed during devitrification of $\mathrm{Na}_{2} \mathrm{O} \cdot \mathrm{Al}_{2} \mathrm{O}_{3} \cdot \mathrm{B}_{2} \mathrm{O}_{3} \cdot \mathrm{SiO}_{2} \cdot \mathrm{Fe}_{2} \mathrm{O}_{3}$ glasses. Journal of Materials Science, 45(5), 2010, 13501353. 